\title{
Modeling Farm Management Modernization: Case Study of Japanese Rice Farming Corporations
}

\author{
Yukio Kinoshita ${ }^{1}$ and Nobuo Kimura ${ }^{2}$ \\ 1. Department of Food Production and Environmental Management, Faculty of Agriculture, Iwate University, Morioka, Iwate \\ 020-8550, Japan
}

2. Emeritus at Iwate University, Morioka, Iwate 020-8550, Japan

\begin{abstract}
While conventional family-owned and family-operated farms remain the most common structure, the number of Japanese agricultural corporations has increased in recent years as a result of changing policies. Some of them are possibly starting to adopt modern corporate management practices to remain viable in a more competitive environment. However, changes in the business structure have not always been accompanied by changes in farm management practices. This study represents a theoretical and empirical investigation into farm modernization practices to provide perspective and recommendations to enhance farm business. Various aspects of farm modernization were considered, including temporal, economic and functional modernization. Critical elements of farm modernization were examined using a structural equation model of surveys, wherein questionnaires were delivered to 2,260 agricultural corporations across Japan in 2014 and 2016, generating 669 usable responses from rice farming corporations. Overall, these corporations demonstrated moderate degrees of modernization, indicating that they have not yet completely transitioned from conventional management styles to modern corporate management and that the farm-household complex system still exists for many of them. It was also found that farm modernization is significantly affected by both production and business management systems, although it was unclear whether a farmer's managerial capabilities were critical for farm modernization. The findings of this study indicate that current farming corporations may benefit from incorporating additional modernization practices. The analytical framework and results will help farmers to better understand their management practices and can be used to provide ideas for policy development to promote competitive farm businesses.
\end{abstract}

Key words: Farm business, farming corporations, modernization of management, structural equation model.

\section{Introduction}

Family-owned and family-operated farms, which are a common business structure in agriculture, are probably starting to adopt modern corporate management practices in Japan. Over the last decade, several agricultural policies have been developed to boost the corporatization of business-orientated family farms and the entry of non-agricultural corporations into farming in Japan. For instance, a farming corporation can benefit from official support programs, such as preferential lending, if its brief business plan is approved by the municipality in which it is located. This has led to an increase in the number of agricultural corporations to 23,158 in 2015 (Table 1)

Corresponding author: Yukio Kinoshita, Ph.D., research field: farm management. and the number of individual farms to 1.34 million. Among these, 6,540 corporations, representing 28\% of all Japanese agricultural corporations, produced rice as the main crop. Furthermore, there has been a seven-fold increase in the entry of corporations from non-agricultural sectors into the agricultural sector following the deregulation of farmland use, particularly since 2009. However, changes in the business structure, such as the involvement of stock corporations and agricultural producers' cooperative corporations, have not always been accompanied by changes in farm management practices.

To remain viable, Japan's agricultural industry needs to become more competitive, particularly if any possible trade arrangements result in more rice being imported from countries that grow short- and 
Table 1 Numbers of agricultural corporations with sales in Japan.

\begin{tabular}{lllll}
\hline \multirow{2}{*}{ Year } & \multicolumn{4}{c}{ Number of agricultural corporations } \\
\cline { 2 - 5 } & 2000 & 2005 & 2010 & 2015 \\
\hline Total & 13,186 & 13,941 & 17,040 & 23,158 \\
Producing rice as the main crop & 1,922 & 1,928 & 3,861 & 6,540 \\
\hline
\end{tabular}

Source: customized data from the Census of Agriculture and Forestry, Ministry of Agriculture, Forestry and Fisheries, Japan.

medium-grain varieties of Japonica rice (Oryza sativa) and Japan's five-decade-old rice-reduction program faces abolition. Numerous potential determinants of competitiveness in agricultural sectors have previously been identified, including farm size, factor intensity, farm specialization, human capital, consumer demand, natural environment, density, facilities, public investments in infrastructures, public policies and regulations, and research and development [1]. Previous studies have compared the overall quantitative measures of the Japanese rice industry, such as the industry's economic efficiency, physical productivity [2, 3], product quality and consumer preference [4-6], with little consideration of internal factors at the farm level, such as, business strategy and management capability, as drivers of farm management modernization.

Japanese rice farmers need to revamp their strategies to adapt to domestic and international changes in agricultural policy. Therefore, a theoretical and empirical investigation into farm modernization practices will provide a new perspective and recommendations to enhance farm business in Japan. Although Kimura [7] emphasized the critical factors required for farm business growth, including management systems, managerial capabilities and modernization practices, the relationships among these factors have not been completely assessed. This study aimed to investigate the relationship between production and business management systems, managerial capabilities, and the modernization of farm management. More specifically, each of these is first described qualitatively and then analyzed quantitatively to examine the modernization of Japanese rice farming corporations.

\section{Materials and Methods}

\subsection{Theoretical Framework}

\subsubsection{Farm Modernization}

Previous literature has pointed out that tasks carried out by farmers have been changing in modern agriculture of developed countries, where farm businesses were earlier mostly owned and operated by families. Gasson and Errington [8] stated that with recent changes in the farm business environment, managerial task maybe come more important than manual and technical tasks on farms, which poses the question as to which managerial tasks were addressed more generally in farm businesses. Hutson [9] claimed that farmers should organize tasks adapting to the modernization of sourcing farm inputs (e.g., family and hired labor, capital and farmland) into their management process. Kingwell [10] summarized that future farmers may benefit more by managerial tasks, such as planning and analyzing at office than by outside tasks on farm; thus, they would involve more and more planning, organizing and monitoring of farm businesses.

With the increasing importance of managerial tasks, the skills required by farmers in modern agriculture have been specified through various case studies of family farms from developed countries [11-14]. Olsson [11] stated that managerial tasks and entrepreneurship of farmers would become essential for future growth in farm businesses. McElwee and Bosworth [13] implied that a wide range of tasks and skills relating to entrepreneurship were required of farmers who develop enterprising-oriented farm businesses. Nuthall [12] revealed that information-gathering and information-using skills 
were critical under more modernized agriculture, and especially, the diffusion of information technology serving well for farm management. Rikkonen et al. [14] emphasized that managerial competence drew attention when farmers addressed a market-driven environment and invested in their business' growth, and especially that their development of a vision and of a long-run business plan for the farm was significant. Other studies noticed managerial behavior as a factor influencing farm business profitability [15, 16]. For example, Kingwell [15] found that time management at work was possibly critical for improving profitability of farm business that faced a more complex situation than before.

Furthermore, it had been emphasized that conventional farm management differs from modern corporate management [17-20]. Internationally, this has been seen as a barrier to competing on a global scale, so transitioning from conventional farm management to modern corporate management is a pressing challenge for farms in developed countries. Specifically, Kimura [17] used two measures to capture the progression from livelihood farming to corporate farming: quantitative measures (farm size and sales) and management styles (business strategies, extent of modernization, management practices and human resource development).

Since family-owned and family-operated farms are a common business structure, farm entities often represent a farm-household complex as individuals, partnerships and occasionally private companies [21, 22]. Thus, there is an intimate relationship between the farm and the family, which naturally leads to conflict over capital and labor allocation. A further difference between the farm-household complex and public company arrangements is that the owners of the former are not usually separated from the business in space or in management, whereas those of the latter are. Thus, the modernization of farm management is considered to involve practices that allow a farm to be split from the farm-household complex and managed as a business to reduce conflict between the families.

According to Kimura [7], modernization requires temporal, economic, functional and spatial changes, all of which are critical for business growth in family farms. More specifically, temporal modernization involves the clear segregation of business hours from private hours; economic modernization involves controlling accounting and financial practices, and isolating business budgets from household budgets; functional modernization relates to organizing and coordinating work duties and separating work and family relationships; spatial modernization requires a separate business and work space. Similarly, Nuthall $[21,22]$ argued that temporal modernization is the separation of the labor component of the farm from the farm-household complex, economic modernization is the separation of the capital component, and spatial modernization is the separation of the spatial component. Functional modernization is not clearly referred to by Nuthall [21, 22], but may be related to the separation of the management component.

Overall, the modernization of management is an essential concept that examines the extent to which modern corporate management has developed in family-owned and family-operated farms. Among these four dimensions of modernization, spatial modernization is the least controllable at the farm level, because, unlike the large-scale farms that are found in the United States of America and Australia, the predominant style of farm residences in the Japanese countryside (and likely other parts of Asia) have spatial structures, in which the living space is not separated from the production space. Consequently, this study focused on temporal, economic and functional modernization, indicators for which are provided in Table 2.

\subsubsection{Management Systems}

From the perspective of farm management systems, the most basic type of infrastructure is the agricultural land, which has traditionally been improved through farmland readjustments, the construction of irrigation 
Table 2 Different aspects of management improvement intended for the modernization of farm management.

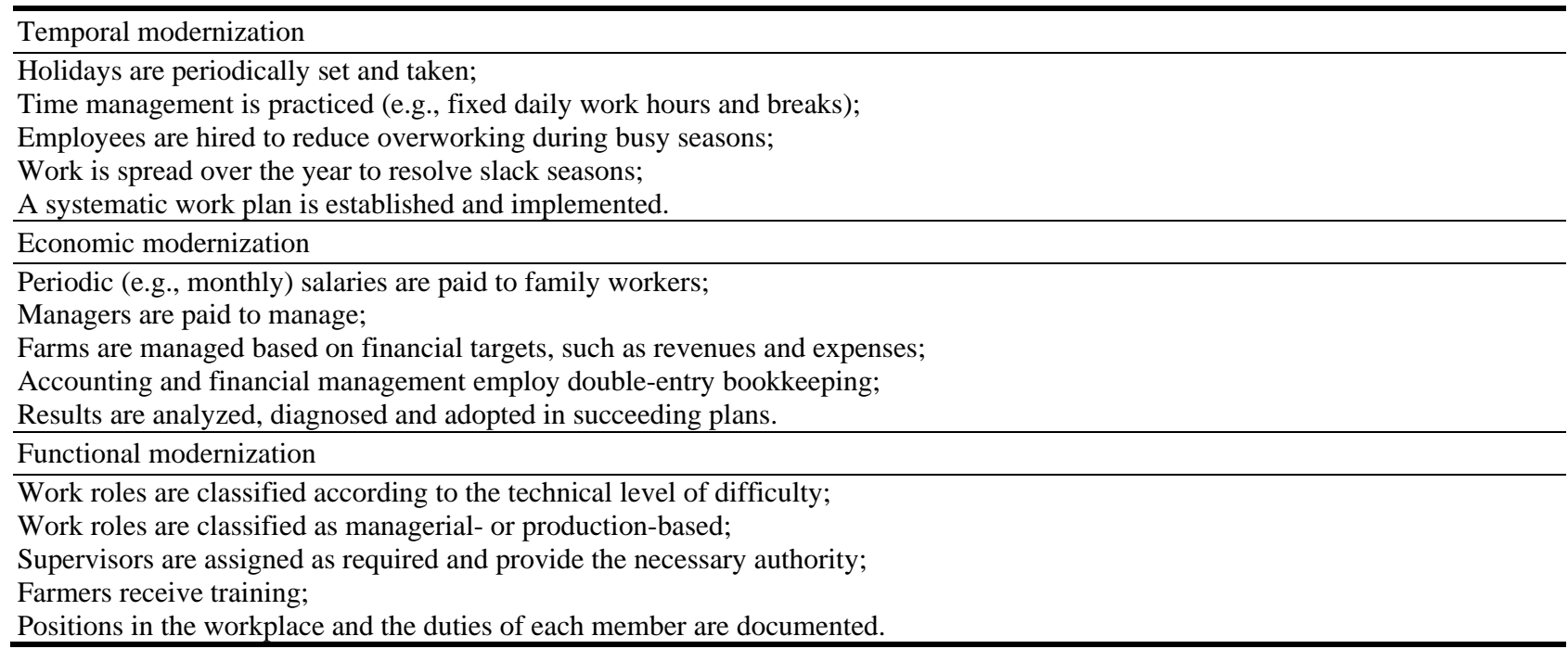

Source: Kimura [7].

and drainage facilities, soil improvement, farmland maintenance, etc.. Investment in fixed equipment, such as farm buildings or farm machinery, has also been of fundamental importance to modern farms. In addition, infrastructure for research and development (R\&D) systems and the introduction of advanced technologies in production systems may also be principal requirements for modern farming, and occasionally for innovation in the production process.

However, in modern farm management, not only is capital investment in infrastructure important for achieving the primary objective of agricultural production, but the installation of various equipment and facilities for farm business management is also becoming increasingly essential. Thus, a separate business and workspace, and the installation of information and communication technology (ICT) in such spaces would affect the modernization of the farm-household complex from a spatial perspective and would help streamline the farm business.

\subsubsection{Managerial Capabilities}

From a human perspective, managerial capability is a crucial driver of farm business viability [7, 17, 23-25]. For example, based on his own data and a review of many other studies, Nuthall [24, 25] revealed a wide range of managerial capabilities that are required in farmers (e.g., technological, observational and planning skills) and identified several factors that may affect these capabilities.

Kimura [17] argued that farm managers need superior skills associated with the three functions of entrepreneurship, adaptability and administration, and also listed specific skills and abilities that are ideally and theoretically required to develop farm management from the livelihood stage to the corporation stage: farmers must first enhance their capabilities as industrialists (“entrepreneurship”) in the livelihood stage and then their capabilities as managers (“administration”) in the corporation stage. In addition, in the face of constant change and uncertainty in the society and economy, farmers should also cultivate their adaptive capability to make their farm viable at any stage of the farm management development process.

Specifically, entrepreneurial capability requires philosophical values, hope and vision, the setting of aggressive targets, entrepreneurial advancement and risk-accepting behavior; adaptive capability requires curiosity, predictive ability and preparedness; administration capability requires an information-gathering ability, rational thinking and analytical behavior. 


\subsection{Survey Method and Sample Data}

A mail survey was used to obtain data from rice farming corporations across Japan. The survey questions explored five issues: (1) the operating structure, including resources, such as the amount of land and labor on the farm, and business tools; (2) management attitudes, including the farming purpose and managerial capabilities; (3) business strategies, including goals and specific planning; (4) the workforce and financial management; (5) sales and marketing. It should be noted that the responses that constituted the data and which the conclusions based on, were self-assessments.

Because of the large number of linkages and variables involved, a large sample size was desirable. Therefore, this survey was sent to directory lists of 2,260 agricultural corporations across Japan provided by private credit agencies in December 2014 and February 2016, which generated 774 usable responses. In this analysis, it was focused specifically on rice farming corporations, which gave a sample size of 669 survey responses, representing approximately $10 \%$ of all Japanese rice farming corporations as of February 2015 (Table 1). Bentler and Chou [26] and Hair et al. [27] suggested that the minimum sample size should be five times the number of parameters being estimated. Therefore, 669 observations were considered for statistical analysis in the final summary model.

Table 3 summarizes the characteristics of the sampled Japanese rice farming corporations. The respondents constituted a tolerably balanced sample in terms of rice industry locations, which mainly included the Hokuriku, Tohoku and Chugoku regions, with relatively fewer respondents from other regions.

The respondents also constituted a tolerably balanced sample in terms of legal status of the farm, although there were relatively fewer agricultural producers' cooperative corporations represented based on the Census of Agriculture and Forestry 2015, 38\% of Japanese rice farming corporations stand as both a limited liability company and a stock corporation, while 54\% are an agricultural producers' cooperative corporation. Individual motivated farmers and community-based farm cooperatives are the two types of Japanese core farmers identified by the general criteria [2]. Individual motivated farmers are typically in the form of commercial enterprises, such as a limited liability company and a stock corporation, with the basic principle of maximizing their profit. In contrast, community-based farm cooperatives are composed of many small family farms and are often in the form of agricultural producers' cooperative corporations with the spirit of mutual assistance.

Given an executing rate of $40 \%$ in a Japanese rice-reduction program, it was estimated that all Japanese rice farming corporations had a mean of 23.2 hectares of the total farmland. This value was calculated from the Census of Agriculture and Forestry 2015, showing a mean of 13.9 hectares allocated only for rice planting out of the total farmland. Therefore, the

Table 3 Characteristics of the sampled Japanese rice farming corporations.

\begin{tabular}{ll}
\hline Number of samples & 669 \\
\hline Response rate & $36 \%$ \\
\hline Region & \\
\hline Hokkaido & $8 \%$ \\
Tohoku & $17 \%$ \\
Hokuriku & $32 \%$ \\
Kanto/Tozan & $10 \%$ \\
Tokai & $4 \%$ \\
Kinki & $4 \%$ \\
Chugoku & $17 \%$ \\
Shikoku & $2 \%$ \\
Kyusyu & $5 \%$ \\
\hline Organization type & \\
\hline Limited liability companies & $21 \%$ \\
Stock corporations & $26 \%$ \\
Agricultural producers' cooperative & $45 \%$ \\
corporations & $9 \%$ \\
Other & \\
\hline Farmland scale & 35.9 ha \\
\hline Mean & 22.4 ha \\
\hline Median & \\
\hline Meales & $(363,478$ USD) \\
\hline Median & \\
\hline Sales have been convertedat a rate 115 & \\
\hline & \\
\hline
\end{tabular}

Sales have been converted at a rate of 115 yen to 1 USD. 
respondents were likely to be tolerably consistent with the overall Japanese population in terms of farmland scale, exhibiting mean scale of 35.9 hectares and median scale of 22.4 hectares. Finally, the respondents were likely to be fairly consistent with the overall Japanese population in terms of sales, exhibiting mean sales of 41.8 million yen and median sales of 27.2 million yen, compared with a mean of 41.2 million yen across all Japanese rice farming corporations according to the Economic Census 2012.

\section{Results and Discussion}

\subsection{Model Development}

The factors included in the model are shown in Fig. 1.
It is hypothesized that the extent of farm management modernization is dependent on how production and business management systems are developed, and how the managerial capabilities of a farm manager are assessed. Therefore, by drawing on the modernization framework, a set of questions were developed (Table 2 ). One point was given for each practice that was complied with, and the points were then summed. Because there are five management practices for each aspect of modernization, the total scores for each ranged from 0 to 5 points. The final results for each aspect are provided in Table 4, which show that economic modernization was the most advanced (3-5 points for most farms), while functional modernization was the least advanced (0-2 points for most farms).

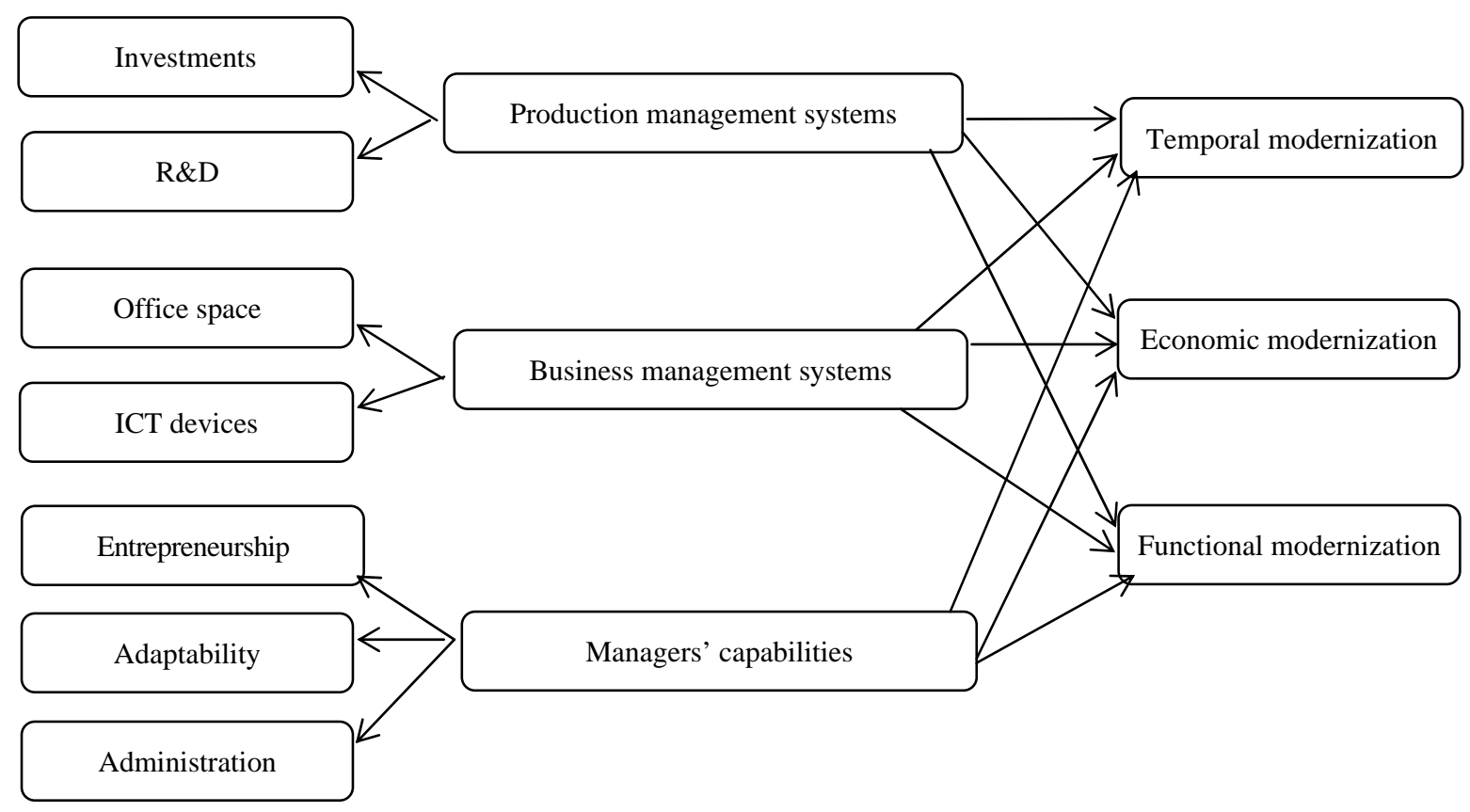

Fig. 1 A structural model of farm modernization.

Table 4 Frequency distribution of the extent of farm modernization.

\begin{tabular}{llll}
\hline Score & Temporal modernization & Economic modernization & Functional modernization \\
\hline 0 & 81 & 74 & 158 \\
1 & 138 & 116 & 128 \\
2 & 154 & 103 & 147 \\
3 & 96 & 120 & 111 \\
4 & 99 & 140 & 77 \\
5 & 101 & 116 & 48 \\
\hline Total number of samples & 669 & 669 & 669 \\
Average of scores & 2.44 & 2.72 & 1.95 \\
Standard deviation & 1.61 & 1.64 & 1.55 \\
\hline
\end{tabular}


Production management systems have traditionally been a major part of farm systems, and are expected to have a greater influence on production management at the field level than personnel and financial management at the non-field level. However, investment and research and development are considered to be related to production management systems, as they effectively support viable and innovative farm business in the long term. By contrast, business management systems are not always an important part of farm systems, particularly in family farms, as farm-household complexes often continue to use conventional practices. These are of more importance in farming corporations, as these are business-oriented and more organized, operating at a larger scale and with more hired workers. Consequently, business management systems are expected to have a large impact on practices relating to personnel and financial management in farming corporations. Furthermore, office space and ICT devices are considered to be related to business management systems, because these are generally required in a modern business environment, including farm businesses.

The managerial capabilities of a farm manager are referred to as “managers' capabilities”. These are generally considered essential to allow a manager to work across various functions in business management, and the same would be true for a farmer, particularly in a farming corporation setting. The constituent elements of entrepreneurship, adaptability and administration are considered to be related to the managers' capabilities to fulfill basic functions in farm management, as previously explained.

Seven items relate to investment and $R \& D$ in production management systems. Investment predictors lead a farm manager to follow his/her prior commitment to investment, investment strategy for mechanization and investment strategy for advanced technology, while $R \& D$ supports a prior commitment to advancing technology, experimental fields, experimental crops and the achievement of production innovations. Six items relate to office space and ICT devices in business management systems. Office space is a predictor of the installation of office buildings/rooms, a calendar of operations and a trading name, while ICT devices help with the installation of software for management, email/website and a mobile phone for the farm business. A further 10 items are associated with entrepreneurship, adaptability and administration in relation to managers' capabilities. Entrepreneurship is a predictor of values, hope and vision, ambitious goal setting, entrepreneurial development and risk-accepting behavior, while adaptability is a predictor of curiosity, predictive ability and preparedness, and administration is a predictor of information-gathering, rational thinking and analytical behavior.

All 23 of these variables were measured in this survey. Thirteen of these were measured as dummy variables (i.e., $1=$ complied with, $0=$ not complied with). The remaining 10 were capability-related questions that were self-rated on the Likert scale with five levels; therefore, these were converted into dummy variables $(1=$ a positive response of "agree" or "strongly agree" and $0=$ a neutral or negative response of "disagree” or "strongly disagree”).

All the observed variables and constructions outlined above were built into a structural equation model that was an expansion of the general model presented in Fig. 1. A schematic diagram of this hypothesized model is shown in Fig. 2. The arrows show the hypothesized direction of influence, each of which represents a linear equation. For example, the linear equation between production management systems (PS) and temporal modernization (TM) is as Eq. (1):

$$
\mathrm{TM}=a+b \mathrm{PS}+e
$$

where, $a=2.444$ and $b=1.000(0.488$ in a standardized form). 


\section{Observed variables}

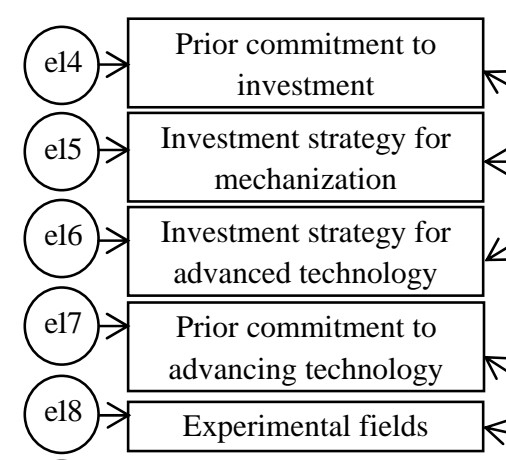

e19 $>>\begin{gathered}\text { Experimental crops } \\ \text { Achievement of production } \\ \text { innovations }\end{gathered}$

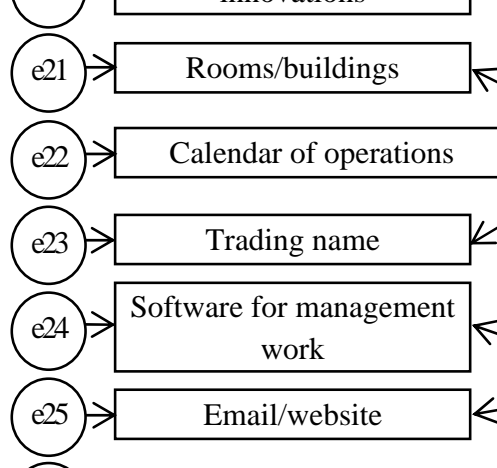

e26

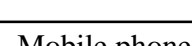

Mobile phone

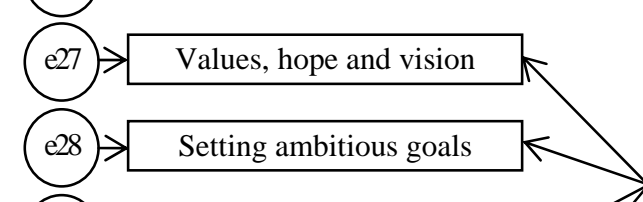

e29 $>$ Entrepreneurial development

e30

Risk-accepting behavior
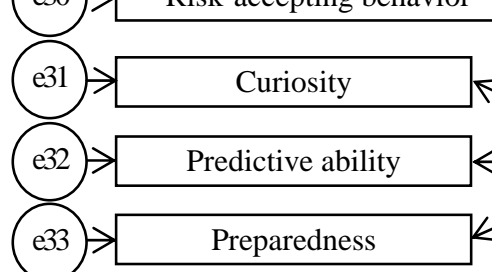

e34 $\rightarrow$ Information-gathering ability

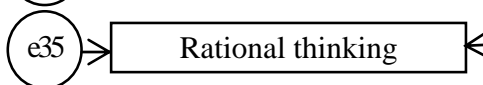

e36

e36

Analytical behavior

Fig. 2 Hierarchical structural equation model of farm modernization depicted as a path diagram.

The variables in rectangular boxes are the observed variables; the variables in the elliptical boxes represent latent variables as independent variables or predictors, the values of which were obtained from the defined relationships; the variables in circles are error terms (labeled e1-e36); the arrows indicate the hypothesized direction of influence. 
Thus, taken together, the arrows provide a set of simultaneous equations, making it possible to determine the parameters for all of the equations, including those for the latent variables, in any given set.

The objective of this study was to determine which variables influence the degree of farm modernization. It was hypothesized that farm modernization depends on the latent variables "production management systems", which contains the two predictors "investments" and "R\&D"; "business management systems", which contains the two predictors "office space” and "ICT devices"; “managers' capabilities”, which contains the three predictors "entrepreneurship," "adaptability" and "administration". None of these variables were directly observed, but they were inferred from their ultimate impact on the observed variables.

\subsection{Testing the Model: Causal Relationships between the Factors Affecting Farm Modernization}

Using the proposed model and the values for all the observed variables, it was possible to calculate the model parameters and "goodness of fit" statistics using the structural equation modeling package IBM SPSS Amos 20. The particular version of the model presented was the culmination of many trials selected on the basis of its compliance with argued logic around farm modernization and its goodness of fit.

The "goodness of fit" parameters of the final model indicated that it was statistically acceptable and supported the farm modernization relationships. No single statistic is used to assess structural equation models. However, the most commonly used is Chi-squared divided by the degrees of freedom (CMIN/df), for which any value below 5 is considered reasonable [28], and 2 or less is considered excellent. The CMIN/df value for this model was 3.122, representing a significance level $<0.001$. Other popular statistics are the "goodness of fit index" (GFI) and "adjusted goodness of fit index" (AGFI). The GFI is a measure of fit between the hypothesized model and the observed covariance matrix [29], while the AGFI corrects the GFI, which is affected by the number of indicators of each latent variable. Both these indices range from 0 to 1 , with a value of over 0.9 generally indicating an excellent model fit. In this case, the GFI was 0.901 and the AGFI was 0.879, further indicating the acceptability of the hypothesized model. Finally, the "root mean square of approximation” (RMSEA) [30] is also often used, which fits the model to the population moments rather than the sample moments and requires a value of less than 0.1 . For this model, the value was 0.056 , with a significance level of 0.006 .

Table 5 provides the relevant regression parameters, including the significance levels, obtained from solving the model. Since the objective of this study was to determine the relationship between the latent variables, the constants are not presented. The standardized regression coefficients are also presented to allow the relative importance of the variables to be assessed since they have different units.

The majority of model parameters were acceptably significant (Table 5). It was found that the latent variables "production management systems" "business management systems" and "managers' capabilities" were most strongly related to economic modernization $\left(R^{2}=0.624\right)$, followed by temporal modernization $\left(R^{2}=0.499\right)$ and functional modernization $\left(R^{2}=0.438\right)$. Among these, production management systems and business management systems were of equal importance to economic modernization, while managers' capabilities were only one-third as important as these. Similarly, managers' capabilities were even less important than both production and business management systems in terms of temporal modernization. By contrast, neither managers' capabilities nor business management systems were particularly important in terms of functional modernization, whereas production management systems were very important. Thus, overall, 
Table 5 Model parameters determining farm modernization.

\begin{tabular}{|c|c|c|}
\hline $\begin{array}{l}\text { Variable pair and relationship direction } \\
\text { (from } \rightarrow \text { to) }\end{array}$ & Standardized regression coefficient & Significance level \\
\hline Production management systems $\rightarrow$ Temporal modernization & 0.488 & - \\
\hline Business management systems $\rightarrow$ Temporal modernization & 0.483 & - \\
\hline Managers’ capabilities $\rightarrow$ Temporal modernization & 0.166 & - \\
\hline Production management systems $\rightarrow$ Economic modernization & 0.545 & $<0.001$ \\
\hline Business management systems $\rightarrow$ Economic modernization & 0.538 & $<0.001$ \\
\hline Managers’ capabilities $\rightarrow$ Economic modernization & 0.195 & $<0.001$ \\
\hline Production management systems $\rightarrow$ Functional modernization & 0.506 & $<0.001$ \\
\hline Business management systems $\rightarrow$ Functional modernization & 0.378 & $<0.001$ \\
\hline Managers' capabilities $\rightarrow$ Functional modernization & 0.200 & $<0.001$ \\
\hline Production management systems $\rightarrow$ Investments & 0.660 & $<0.001$ \\
\hline Production management systems $\rightarrow$ R\&D & 0.390 & $<0.001$ \\
\hline Business management systems $\rightarrow$ Office space & 0.981 & $<0.001$ \\
\hline Business management systems $\rightarrow$ ICT devices & 0.905 & $<0.001$ \\
\hline Managers' capabilities $\rightarrow$ Entrepreneurship & 0.967 & $<0.001$ \\
\hline Managers' capabilities $\rightarrow$ Adaptability & 1.000 & $<0.001$ \\
\hline Managers' capabilities $\rightarrow$ Administration & 0.991 & $<0.001$ \\
\hline Investments $\rightarrow$ Prior commitment to investment & 0.499 & - \\
\hline Investments $\rightarrow$ Investing strategy for mechanization & 0.446 & $<0.001$ \\
\hline Investments $\rightarrow$ Investing strategy for advanced technology & 0.374 & $<0.001$ \\
\hline R\&D $\rightarrow$ Prior commitment to advancing technology & 0.260 & $<0.001$ \\
\hline R\&D $\rightarrow$ Experimental fields & 0.677 & - \\
\hline R\&D $\rightarrow$ Experimental crops & 0.545 & $<0.001$ \\
\hline R\&D $\rightarrow$ Achievement of production innovations & 0.217 & $<0.001$ \\
\hline Office space $\rightarrow$ Office buildings/rooms & 0.540 & - \\
\hline Office space $\rightarrow$ Calendar of operations & 0.439 & $<0.001$ \\
\hline Office space $\rightarrow$ Trading name & 0.449 & $<0.001$ \\
\hline ICT devices $\rightarrow$ Software for management work & 0.416 & - \\
\hline ICT devices $\rightarrow$ Email/website & 0.615 & $<0.001$ \\
\hline ICT devices $\rightarrow$ Mobile phones & 0.276 & $<0.001$ \\
\hline Entrepreneurship $\rightarrow$ Values, hope, and vision & 0.629 & - \\
\hline Entrepreneurship $\rightarrow$ Setting ambitious goals & 0.618 & $<0.001$ \\
\hline Entrepreneurship $\rightarrow$ Entrepreneurial development & 0.607 & $<0.001$ \\
\hline Entrepreneurship $\rightarrow$ Risk-accepting behavior & 0.548 & $<0.001$ \\
\hline Adaptability $\rightarrow$ Curiosity & 0.604 & - \\
\hline Adaptability $\rightarrow$ Predictive ability & 0.417 & $<0.001$ \\
\hline Adaptability $\rightarrow$ Preparedness & 0.637 & $<0.001$ \\
\hline Administration $\rightarrow$ Information-gathering & 0.599 & - \\
\hline Administration $\rightarrow$ Rational thinking & 0.426 & $<0.001$ \\
\hline Administration $\rightarrow$ Analytical behavior & 0.574 & $<0.001$ \\
\hline
\end{tabular}

-: it was not possible to calculate a significance level since these variables are latent.

production management systems have a strong impact on all three kinds of modernization, while business management systems affect some types of modernization, and managers' capabilities have little effect on any kind of modernization. This demonstrates that useful and relevant production and business management systems should be developed by farms to promote their modernization.

Considering the latent variable "production management systems" the strongest predictor was "investments" $\left(R^{2}=0.436\right)$, while "R\&D" was very weak $\left(R^{2}=0.152\right)$. Investment reflects a prior commitment to investment by farm management, rather than which production input was strategically invested in, while R\&D reflects experimental activities at the farm level.

Considering the latent variable "business management systems", both the predictors ("office space” and "ICT devices”) were very significant $\left(R^{2}=\right.$ 0.963 and 0.819 , respectively). These high coefficients indicate that a farm with a full complement of business management systems will allocate specific 
business management space on the farm, and then install ICT devices, such as a personal computer with some software for business use in its management space.

Considering the latent variable "managers' capabilities", "adaptability" $\left(R^{2}=1.000\right)$, "administration" $\left(R^{2}=0.982\right)$ and "entrepreneurship" $\left(R^{2}=0.934\right)$ were all very significant. It was suggested that a capable manager will have a wide range of excellent skills that fulfill the functions of entrepreneurship, adaptability and administration in farm management. Among the ideal skills and abilities for a farm manager listed by Kimura [17], this result demonstrates the following specific skills and abilities: a manager with fertile entrepreneurship skills will have strong philosophical values, hopes and vision, aggressive targets, entrepreneurial advancement and risk-accepting behavior; a manager with great adaptability will have preparedness and curiosity; and a manager with perfect administration skills will exhibit information-gathering and analytical behaviors.

\subsection{Implications toward Farm Management}

Modernization

Ideally, farming corporations should adopt management styles that are independent of the household entity, as is generally the case with public companies. However, the data shown in Table 4 indicate that the Japanese rice farming corporations surveyed have not yet fully transitioned from conventional management styles to modern corporate management, as they did not comply with most of the conditions relating to farm modernization. It was expected that the farm-household complex system would still remain for a lot of the Japanese farming corporations. Compliance with certain conditions could be explained by the formal and legal requirements for the corporatization of a farm, such as establishing working regulations, introducing double-entry bookkeeping, and paying salaries and management remunerations for tax purposes. These requirements have partly enhanced temporal and economic modernization. However, Japanese farming corporations may benefit from incorporating additional modernization practices, raising the question of how a manager of farm corporations should push for further modernization of the farm.

The model testing of this study showed that certain practices and related factors had a particular effect on the modernization of Japanese rice farming corporations. For example, economic modernization was greatly enhanced by both production and business systems. One of the effective practices that related to production systems was giving priority to investment in farm management. This may help a farm manager to consider a longer-term business plan with the view of investment and finance. Another effective practice that related to business systems was the installation of software for management use in an office. This practice may help a farm manager to efficiently and accurately manage financial work.

Temporal modernization was also enhanced through production and business systems, albeit to a lesser extent than economic modernization. In this context, some effective practices that related to production systems were the pursuit of capital-intensive farming by investing in machinery and giving priority to investment in farm management. These practices may help a farm manager to manage farm work more rationally to improve labor productivity. Another effective practice that related to business systems was the installation of office space with ICT devices. This practice may help a farm manager to manage time more effectively, separating work time on the farm from non-work time at home. However, there will always be natural constraints on time management on farms as a result of seasonal or unstable production processes, meaning that temporal modernization will be much more difficult to achieve than for general businesses.

Functional modernization has not seen as much 
progress as economic or temporal modernization. Japanese rice farming corporations are not yet well organized, which implies that family-based relationships are still at play even in farming corporations. Nevertheless, functional modernization was also more greatly enhanced by production systems, rather than business systems or the manager's capability. Production systems with greater mechanization may help a farm manager to rationally manage operations in the field rather than in an office.

The model used in this study clearly demonstrates that essential factors, such as entrepreneurship, adaptability and administration, support the specific capabilities of managers in Japanese rice farming corporations. However, it is difficult to assert that a farmer's managerial capabilities are critical to farm modernization, as none of the regression coefficients of the managerial capabilities were strong for any type of modernization in this model. It was not clear why a gap existed between managers' capabilities and the extent of farm modernization, but it is possible that even a farm manager with high capabilities may not have enough know-how about workforce and financial management. If this is the case, providing education and training to managers to acquire the relevant knowledge and skills would be effective in advancing the modernization of Japanese rice farming corporations. Alternatively, because of the weak link between managers' capabilities and modernization of farm management, even a corporatized farm could remain too unorganized for managers' capabilities to be effectively modernized. Further investigation of how the capabilities of farm managers contribute to performance in areas other than farm management modernization would also be of interest, because they are generally crucial drivers of farm business viability.

Meanwhile, increasing the scale of farming is expected to have a positive effect on farm management modernization. However, in any version of the developed model among the culmination of many trials, the scale of farmland had not been found as a significant predictor of modernization. At this point, it should be considered that in the sample data invested in the study, different types of farms, such as a limited liability company, a stock corporation and an agricultural producers' cooperative corporation, are mixed, while the distribution of farmland scale was similar in any types of farms. Many individual motivated farmers in the form of commercial enterprises would be keen on modernizing their farm management practices, often by increasing the scale of the business and hired labor. In contrast, most agricultural producers' cooperative corporations, presumably, still remain as the farm-household complex system containing conventional family farms, even if those are corporatized just to increase their farmland scale. Therefore, when developing a model, the effect of difference in the farmland scale on modernization could be confused with a similar effect of difference in the legal status of the farm. As emphasized by Kinoshita and Oikawa [31], this implies that conditions, such as corporatization and enlargement of the farm, are not enough as triggers but just requirements for progressing modernization of farm management.

Suggestively, the findings of this study will help farmers to better understand their management practices in the face of intensified global competition, which particularly raises challenges for family-owned and family-operated farms. It is important for farming corporations to adapt their management practices so that they can quickly respond to changing market and policies. If corporatized farms are likely to be popular in Japan as a result of international pressures and changes in policy, the particular challenge that will need to be addressed by researchers and policy makers is to more clearly specify what the ideal and workable management system is and what measures are helpful for realizing such management in farming corporations to promote competitive farm businesses. More specifically, the extension of the financial support policy that traditionally focuses on production 
systems (e.g., the introduction of larger machinery) to include investments in business systems at the farm level (e.g., ICT devices for management use) could help in improving farm business viability.

\section{Conclusions}

To assess the factors that impact farm modernization, the farm management practices carried out by Japanese rice farming corporations that differ from the conventional management of family farms were analyzed. Also a suitable model was developed to describe the factors that affect farm modernization. Overall, investment in both production and business systems is important for helping farms to modernize, while the sample farms are halfway through the modernization of their farm management practices. Thus, Japanese rice farmers should incorporate such investments into their competitive strategies.

\section{Acknowledgments}

This research was supported by JSPS KAKENHI, Grant Number 15K03642. The authors would like to thank Teikoku Databank, Ltd. and Tokyo Shoko Research, Ltd. for the provision of directory lists.

\section{References}

[1] Organization for Economic Cooperation and Development. 2011. Fostering Productivity and Competitiveness in Agriculture. Paris: Organization for Economic Cooperation and Development.

[2] Organization for Economic Cooperation and Development. 2009. "Evaluation of Agricultural Policy Reforms in Japan.” Accessed June 15, 2009. http://www.oecd.org/japan/42791674.pdf.

[3] Kawasaki, K. 2010. “The Costs and Benefits of Land Fragmentation of Rice Farms in Japan." Australian J. Agri. Res. Econ. 52 (4): 509-26.

[4] Wailes, E. J., Young, K. B., and Cramer, G. L. 1993. "Rice and Food Security in Japan: An American Perspective.” In Japanese and American Agriculture: Tradition and Progress in Conflict, edited by Tweeten, L., Dishon, C. L., Chern, W. S., Imamura, N., and Morishima, M. Boulder, US: Westview Press, 377-93.

[5] Ito, S., Rosegrant, M. W., and Agcaoili-Sombilla, M. C. 1995. "Quality-Equivalent and Cost-Adjusted Measurement of International Competitiveness in Japanese Rice Markets.” EPTD Discussion Papers 12, International Food Policy Research Institute. Accessed August, 1995. http://ageconsearch.umn.edu/bitstream/42818/2/eptdp12. pdf.

[6] Peterson, H. H., and Yoshida, K. 2004. "Quality Perceptions and Willingness-to-Pay for Imported Rice in Japan.” J. Agri. Appl. Econ. 36 (1): 123-41.

[7] Kimura, N. 2004. Growth Theory of Modern Farm Business. Tokyo: Association of Agriculture and Forestry Statistics. (in Japanese)

[8] Gasson, R., and Errington, A. 1993. The Farm Family Business. Wallingford, UK: CAB International.

[9] Hutson, J. 1987. "Fathers and Sons: Family Farms, Family Businesses and the Farming Industry.” Sociology 21 (2): 215-29.

[10] Kingwell, R. 2002. "Issues for Farm Management in the 21st Century: A View from the West.” Agribusiness Review 10. Accessed September 10, 2002. http://www.agrifood.info/review/2002/Kingwell.pdf.

[11] Olsson, R. 1988. "Management for Success in Modern Agriculture.” Euro. Rev. Agri. Econ. 15: 239-59.

[12] Nuthall, P. L. 2006. "Determining the Important Management Skill Competencies: The Case of Family Farm in New Zealand.” Agri. Systems 88 (2-3): 429-50.

[13] McElwee, G., and Bosworth, G. 2010. "Exploring the Strategic Skills of Farmers across a Typology of Farm Diversification Approaches.” J. of Farm Management 13 (12): 819-38.

[14] Rikkonen, P., Mäkijärvi, E., and Ylätalo, M. 2013. "Defining Foresight Activities and Future Strategies in Farm Management: Empirical Results from Finnish FADN Farms.” Int. J. of Farm Management 3 (1): 3-11.

[15] Kingwell, R. 2011. "Managing Complexity in Modern Farming.” Australian J. Agri. Res. Econ. 55 (1): 12-34.

[16] Wilson, P. 2011. "Decomposing Variation in Dairy Profitability: The Impact of Output, Inputs, Prices, Labour and Management.” J. Agri. Sci. 149 (4): 507-17.

[17] Kimura, N. 2008. Management of Modern Agriculture. Tokyo: Nihon Keizai Hyouronsya Ltd.. (in Japanese)

[18] Malcolm, B., Makeham, J., and Wright, V. 2005. The Farming Game: Agricultural Management and Marketing, 2nd ed.. Melbourne: Cambridge University Press.

[19] Olson, K. D. 2011. Economics of Farm Management in a Global Setting. Hoboken, US: John Wiley and Sons, Inc..

[20] Kay, R. D., Edwards, W., and Duffy, P. A. 2012. Farm Management, 7th ed.. New York: McGraw Hill Higher Education.

[21] Nuthall, P. L. 2011. Farm Business Management: The Analysis of Farming Systems. Oxfordshire, U.K.: CABI International. 
[22] Nuthall, P. L. 2016. Farm Business Management: The Fundamentals of Good Practice. Boston, US: CABI International.

[23] Muggen, G. 1969. "Human Factors and Farm Management: A Review of the Literature.” World Agri. Econ. Rural Socio. Abs. 11 (2): 1-11.

[24] Nuthall, P. L. 2009. Farm Business Management: The Human Factor. Oxfordshire, UK: CABI International.

[25] Nuthall, P. L. 2009. "Modelling the Origins of Managerial Ability in Agricultural Production.” Australian J. Agri. Res. Econ. 53 (3): 413-36.

[26] Bentler, P. M., and Chou, C. P. 1987. "Practical Issue in Structural Modeling.” Socio. Methods and Res. 16 (1): 78-117.

[27] Hair, J. F., Anderson, R. E., Tatham, R. L., and Blake, W. C. 1995. Multivariate Data Analysis with Readings, 4th ed.. Englewood Cliffs, N.J.: Prentice Hall.

[28] Carmines, E. G., and McIver, J. P. 1981. "Analyzing Models with Unobserved Variables.” In Social Measurement: Current Issues, edited by Bohrnstedt, G. M., and Borgatta, E. F. Beverly Hills: SAGE, 61-73.

[29] Jöreskog, K. G., and Sörbom, D. 1984. LISREL VI User's Guide, 3rd ed.. Mooresville, Indiana: Scientific Software, Inc..

[30] Browne, M. W., and Cudeck, R. 1993. "Alternative Ways of Assessing Model Fit.” In Testing Structural Equation Models, edited by Bollen, K. A., and Long, J. S. Newbury Parrk, C.A.: SAGE, 136-62.

[31] Kinoshita, Y., and Oikawa, M. 2015. "The Reality of Paddy Farming and New Issue on Land Improvement Districts.” Water, Land and Environ. Eng. 83 (11): 39-43. (in Japanese) 